
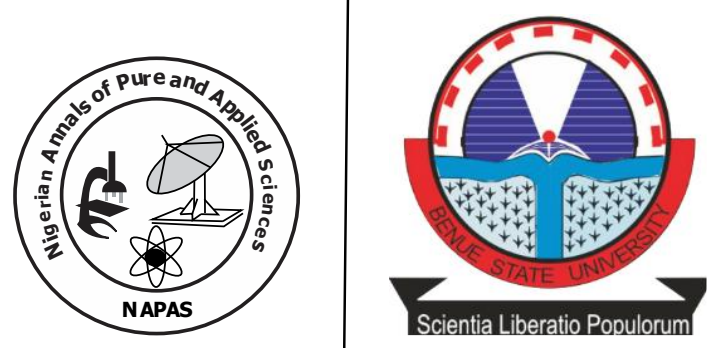

\title{
Derangement in Enzymatic and Non-Enzymatic Markers of Liver Function in Human Immunodeficiency Virus (HIV) Infected Patients in Makurdi, North Central Nigeria
}

Ochalefu, D.0.1, Adoga, G.I. ${ }^{2}$, Alonyenu, E.I. ${ }^{1}$ and Agada, S.A. ${ }^{1}$

Department of Medical Biochemistry, College of Health Sciences, Benue State University, Makurdi, Nigeria. ${ }^{1}$

Department of Biochemistry, College of Medicine, University of Jos, Jos, Plateau State, Nigeria. ${ }^{2}$

Correspondence Author: dickochalefu@gmail.com.

\begin{abstract}
Liver disease has emerged as a critical issue in the management of human immunodeficiency virus (HIV) victims. This study was carried out to investigate the derangement in indices of liver function in HIVinfected patients in Makurdi, North Central Nigeria. One hundred and fifty males and females adults within the age range of 21-50 years were enrolled for this study. One hundred of these participants were confirmed HIV positive, out of which fifty were on various antiretroviral drugs including the nucleoside / nucleotide reverse transcriptase inhibitors and the non-nucleoside transcriptase inhibitors classes of antiretroviral drugs. The remaining fifty persons who were HIV- negative served as the control group. Blood samples from the studied persons were analysed for alanine aminotransferase, aspartate aminotransferase, alkaline phosphatase, total protein, albumin, total bilirubin and conjugated bilirubin using automated clinical chemistry analyser, Hitachi 902 (Roche Diagnostic GMBH, Germany). The HIV-patients with or without antiretroviral drugs had their serum levels of alanine aminotransferase, aspartate aminotransferase and alkaline phosphatase significantly raised $(\mathrm{p}<0.05)$ compared with the control subjects. A significant rise $(p<0.05)$ was observed in serum level of total protein in the HIV patients who were yet to commence antiretroviral drugs when compared to the control subjects. However, the albumin levels of the HIV patients on the antiretroviral drugs and those who were yet to commence the antiretroviral drugs decreased significantly $(\mathrm{p}<0.05)$ when compared with that of the control. The total bilirubin level of the HIV patients on antiretroviral drugs showed significant increase $(p<0.05)$ compared with the control subjects and the HIV patients who were not on antiretroviral drugs. This study reveals that both HIV infection itself and the antiretroviral drugs cause hepatic malfunction.
\end{abstract}

Keyword: Human immunodeficiency virus, Enzymatic markers, Non-enzymatic markers, Antiretroviral drugs. 


\section{Introduction}

The advent and use of highly active antiretroviral therapy which consists of the nucleoside / nucleotide reverse transcriptase inhibitors, non-nucleoside reverse transcriptase inhibitors, integrase inhibitors, entry inhibitors, protease inhibitors and post attachment inhibitors in the management of human immunodeficiency virus (HIV) infected patients has put smile on the faces of these patients since the medication leads to nonprogressive viral infection and increases their life span (Mastroianni, Lichtner and Mascia, 2014). Since HIV patients now live for longer period, it is imperative to investigate the functional status of the vital organs like the liver, kidney and the heart in this category of patients with a view to ascertaining the effect of this disease and or the highly active antiretroviral therapy on these organs.

Previous studies show that the complex nature of the medication used in antiretroviral therapy makes it difficult to understand the independent contribution of the individual drug in the development of liver injury by the drugs (Mankhatithan et al., 2011; Sulkowski, 2004). As a result of the foregoing, the prevention and management of liver injury due to antiretroviral therapy has emerged as a major concern in the treatment of HIV/AIDS patients (Law, Dore and Duncombe, 2003; Mankhatithan et al., 2011; Wondemagegn et al., 2013). The longer HIV- infected patients live, the more they are predisposed to developing long term manifestations of long standing HIV infection and treatment complications (Emejulu, Ujowundu and Igwe, 2010). The destruction of the liver cells (hepatocytes) results in the release to the plasma the marker enzymes: aspartate aminotransferase, alanine aminotransferase and alkaline phosphatase (Mankhatithan et al., 2011). The analyses of the activities of these enzymes in the plasma are used to indirectly assess the activity of the liver. A rise in the plasma concentrations of these enzymes above the homeostatic limits implies a disorder to the liver tissue (Friday, Iniobong and Moses, 2010). In addition, abnormalities in the serum levels of total protein, albumin, total and conjugated bilirubin are used in assessing the functional status of the liver (Okpa et al., 2015; Jemikalajah and Adu, 2015).

In this study the enzymatic markers (alanine aminotransferase, aspartate aminotransferase and alkaline phosphatase) and non- enzymatic markers (total protein, albumin and bilirubin) of the functional status of the liver in HIV patients with or without highly active antiretroviral drugs are investigated. Although some studies have been carried out on liver function in HIV patients elsewhere, there is lack of wealth of information in Makurdi.

\section{Materials and Methods}

A total of one hundred and fifty persons selected over three months duration from the HIV/AIDS clinic and the blood bank of the Federal Medical Centre, Makurdi were used for the study. They were stratified into 3 groups of fifty persons each. Group 1 comprised of fifty persons confirmed to be negative for HIV antibodies. These were blood donors at the blood bank who were used as the control subjects, group 2 consisted of fifty persons confirmed HIV positive but were yet to start antiretroviral therapy whereas group 3 was made up of fifty confirmed HIV patients who were already on antiretroviral drugs.

The HIV status of the participants was confirmed using Western Blot. The subjects comprised of adults of both sexes of age range 21- 50 years. The nature and purpose of the research were explained to the participants and they consented to it. Structural questionnaires were administered to the participants in order to obtain their demographic data and clinical history. It was ensured that the participants had no hepatitis B, C and E and that they had no past history suggestive of liver or renal disease.

\section{Ethical Consent}

The study was approved by the Ethical Committee on research of the Federal Medical Centre Makurdi, Benue State, Nigeria.

\section{Sample Collection}

Five milliliters of blood sample each were collected by venepuncture from the 
participants. The site of collection was sterilized with cotton wool soaked in $70 \%$ alcohol. The blood samples were collected with minimal stasis (to prevent haemolysis) using disposable syringes and needles; and were put into plain sample bottles. These were allowed to stand at room temperature for the blood to clot and retract. This was followed by centrifugation at $4000 \mathrm{rpm}$ for 4 minutes. Analyses of the samples were done within twenty-four hours. Universal Safety measures were considered while handling the blood samples.

\section{Determination of Biochemical Parameters}

An Automated Clinical Chemistry Analyser, Hitachi 902 (Roche Diagnostic GMBH, Germany) was used to analyze alanine aminotransferase, aspartate aminotransferase, alkaline phosphatase, total protein, albumin, total bilirubin and conjugated bilirubin.

\section{Statistical Analysis}

The data obtained were analyzed for Mean \pm Standard Deviation. The level of significance was set at $\mathrm{p}<0.05$ confidence limit using paired student's t- test.

\section{Results}

There was significant rise $(\mathrm{p}<0.05)$ in the serum levels of alanine aminotransferase, aspartate aminotransferase and alkaline phosphatase of the HIV patients without antiretroviral drugs and those of the patients on antiretroviral drugs when compared with the control subjects. While there was no significant difference $(p<0.05)$ in the serum levels of alanine aminotransferase in both HIV patients on antiretroviral drugs and those who were yet to commence the treatment, the serum level of aspartate aminotransferase in the HIV patients on antiretroviral drugs decrease significantly ( $p$ $<0.05$ ) from those of the HIV patients yet to be treated with antiretroviral drugs. There was significant rise $(p<0.05)$ in the serum level of alkaline phosphatase of the HIV patients on antiretroviral drugs when compared with those living with the virus but had not commenced antiretroviral therapy (Table 1).

The serum total protein of the HIV patients who were yet to commence antiretroviral drugs increased significantly $(\mathrm{p}<$ $0.05)$ when compared with the control subjects. Treatment with antiretroviral drugs was seen to reduce the serum total protein significantly ( $p$ $<0.05)$ when compared with those of the HIV patients without antiretroviral drugs. The HIV patients on antiretroviral drugs and those not on antiretroviral drugs had their serum albumin levels reduced significantly ( $\mathrm{p}<0.05)$ when compared with those of the control subjects. The albumin level of the patients without antiretroviral drugs decreased significantly $(\mathrm{p}<0.05)$ when compared with HIV patients that are on antiretroviral drugs. There was significant rise $(p<0.05)$ in the serum level of total bilirubin of the HIV patients on antiretroviral drugs when compared with those of the HIV-positive patients that were yet to commence antiretroviral drugs and those of the control subjects. The total bilirubin level of the HIV patients without antiretroviral drugs did not show any significant difference $(p>0.05)$ when compared with those of the control subjects. The serum levels of conjugated bilirubin of both the HIV patients on antiretroviral drugs and those not on antiretroviral drugs did not show any significant difference $(\mathrm{p}>0.05)$ when compared with that of the control subjects (Table 1). 
Table 1: Serum levels of liver marker enzymes, total protein, albumin and bilirubin in HIV patients and normal subjects.

\begin{tabular}{|c|c|c|c|}
\hline Parameter & Control & $\begin{array}{l}\text { HIV positive without } \\
\text { antiretroviral drugs }\end{array}$ & $\begin{array}{l}\text { HIV positive on } \\
\text { antiretroviral drugs }\end{array}$ \\
\hline $\begin{array}{l}\text { Alanine } \\
\text { aminotransferase } \\
\text { (IU/L) }\end{array}$ & $24.84 \pm 7.30$ & $28.20 \pm 17.16^{\mathrm{a}}$ & $28.97 \pm 15.15^{\mathrm{a}}$ \\
\hline $\begin{array}{l}\text { Aspartate } \\
\text { aminotransferase } \\
\text { (IU/L) }\end{array}$ & $31.84 \pm 7.93$ & $35.34 \pm 14.14^{\mathrm{a}}$ & $33.54 \pm 20.22^{\mathrm{ab}}$ \\
\hline $\begin{array}{l}\text { Alkaline phosphatase } \\
\text { (U/I) }\end{array}$ & $73.26 \pm 24.63$ & $103.60 \pm 36.46^{\mathrm{a}}$ & $120.28 \pm 48.42^{\mathrm{ab}}$ \\
\hline Total protein $(\mathrm{G} / \mathrm{L})$ & $83.35 \pm 6.46$ & $87.52 \pm 9.26^{\mathrm{a}}$ & $83.00 \pm 6.52^{\mathrm{b}}$ \\
\hline Albumin (G/L) & $44.91 \pm 3.38$ & $38.74 \pm 3.80^{\mathrm{a}}$ & $41.44 \pm 3.22^{\mathrm{ab}}$ \\
\hline $\begin{array}{l}\text { Total bilirubin } \\
(\mu \mathrm{mol} / \mathrm{L})\end{array}$ & $10.03 \pm 3.45$ & $10.76 \pm 5.54$ & $14.57 \pm 3.71^{\mathrm{ab}}$ \\
\hline $\begin{array}{l}\text { Conjugated bilirubin } \\
(\mu \mathrm{mol} / \mathrm{L})\end{array}$ & $2.05 \pm 0.89$ & $2.68 \pm 1.62$ & $2.50 \pm 1.34$ \\
\hline
\end{tabular}

Results with superscripts show significant difference $(\mathrm{p}<0.05)$.

$\mathrm{a}=$ statistically significant from normal control $(\mathrm{p}<0.05)$.

$\mathrm{b}=$ statistically significant from HIV positive without antiretroviral drugs $(\mathrm{p}<0.05)$.

\section{Discussion}

The abnormalities observed in the serum levels of the aminotransferases, alkaline phosphatase, total protein, albumin, and total bilirubin indicate poor hepatic function (Subir et al., 2013). The significant rise $(\mathrm{p}<0.05)$ in the serum levels of alanine aminotransferase, aspartate aminotransferase and alkaline phosphatase agrees with the findings of previous independent studies of Derick et al (2015) and Dusingize et al (2015) on HIV patients. These enzymes are found in the cytosol therefore their blood concentrations are normally low but whenever there is increased cell membrane permeability, hepatocellular injuries and necrosis of the liver cells, they are released into the blood circulation leading to increase in their concentrations in the blood (El- Hosseiny et al., 2016).

The HIV is known to cause a direct damage to the hepatic cells through the gp 120 receptor which triggers metabolic pathway that results in the formation of reactive oxygen species (ROS). The ROS damages the liver cells leading to the release into the plasma of these liver marker enzymes (Mastroiami et al., 2014). The antiretroviral drugs are known to adversely affect liver cells in many ways which include causing metabolic abnormalities, fat accumulation in the hepatocytes, mitochondrial toxicity and insulin resistance (Hurlimann, Weber, Enseleit and Luscher, 2005). When these drugs cause injury to the mitochondria leading to mitochondrial dysfunction there is an initiation of a sequence of events beginning with lipid accumulation, membrane deterioration and the disruption of other energy dependent processes that subsequently result in necrosis (Chwiki et al., 2017). Mitochondrial dysfunction leads to the impairment of mitochondrial fatty acid $\beta$ - oxidation, tricarboxylic acid cycle and oxidative phosphorylation resulting in intracellular lipid accumulation. This contributes to the resulting hepatotoxicity which culminates in elevated serum liver enzymes (Chwiki et al., 2017).

The significant rise in serum total protein level of the HIV positive patients without antiretroviral drugs in our study concurs with the findings of Arinola et al 
(2005); Sarro et al (2010) and Kapenberg et al (2004). Our result, however, disagrees with earlier report of Okpa et al (2015) that serum total protein in HIV patients decreased significantly when compared with the control subjects.

The significant increase in serum total protein level in this work may be due to increased immunoglobulins (Arinola et al., 2005). The elevation in immunoglobulin levels may be attributed to polyclonal $\beta$ - cell activation as the HIV disease advances. The polyclonal $\beta$ - cell activation is induced by viral envelope proteins especially glycoprotein 41 to produce excess abnormal immunoglobulins (Arinola et al., 2005; Jemikalajah and Adu, 2015).

The significant decrease $(\mathrm{p}<0.05)$ in the serum albumin level of the HIV positive patients in our finding is in consonance with the result obtained by Dusingize et al (2015); Ibeh et al (2013) and Subir et al 2013. Albumin is a protein produced in the liver. It transports substances like hormones, drugs and waste products through the blood (Melashu et al., 2016). The significant fall in the level of albumin in this study may be as a result of malnutrition or chronic inflammation common in HIV/AIDS infection. This is because albumin is a negative acute phase reactive protein whose level can be depressed by elevated levels of tumour necrosis factor (TNF) and interleukin - 1 (IL-1) during chronic inflammation (Mehta et al., 2006; Jemikalajah and Adu, 2015).

The significant rise $(p<0.05)$ in the serum level of total bilirubin seen in the HIV positive patients on antiretroviral drugs agrees with the findings of Subir et al (2013) and Vanwagner and Green (2015) who in their independent studies observed significant elevation in serum total bilirubin of HIV patients on antiretroviral drugs. Bilirubin is a waste product from the breakdown of the red blood cells. Prior to its passage through the liver where it is mixed with sugars to become water soluble, it is referred to as indirect or unconjugated bilirubin. As it passes through the liver, it is processed and then called direct or conjugated bilirubin. A damaged liver may be unable to process bilirubin resulting in an increase in total bilirubin level as seen in our finding (Vanwagner and Green, 2015; Periklis, Efstathios, Angelos and Dimitios, 2017).

\section{Conclusion}

This work unveiled abnormal changes in serum levels of alanine aminotransferase, aspartate aminotransferase, alkaline phosphatase, albumin, total protein, and total bilirubin in victims of the human immunodeficiency virus infection, both those on the antiretroviral drugs and those who were yet to commence the drugs. Liver function is, therefore, compromised in HIV infection.

\section{References}

Arinola, O.G., Salimonu, L.S., Okiwelu, O.H., and Muller, C. P. (2005). Levels of immunoglobulin classes, acute phase proteins and serum electrophoresis in Nigerians infected with HIV. European Journal of Scientific Research, 7(3): 3444.

Chwiki, S.B.S., Campos, M.M., Mclaughlin, M.E., Kleiner, D.E., Kovacs, J.A., Morse, C.G., and Abu-Asab, S.M. (2017). Adverse effects of antiretroviral therapy on liver hepatocytes. Perspective Ultra Struc. Pathol., 41 (2): 186-195.

Derick, N.M.O., Christian, O., Vincent, F., Isaac, A., and Mavis, D. (2015). Hepatic enzyme alterations in HIV patients on antiretroviral therapy. A case - control study in a hospital setting in Ghana. PLOS One, 10 (8); e013449.

Dusingize, J.C., Donald, R., Shi, H.Q., Mutimura, E., Rudakemwa, E., Ndacyayisenga, V., Gakindi, L., Mulvihill, M., Sinayobye, J., Musabeyezu, E., Anastos, K. (2015). Association of abnormal liver function parameters with HIV serostatus and CD4 count in antiretroviral naïve Rwandan women. AIDS Res. Hum. Retroviruses, 31(7): 723-730.

Effiong, E.E., Igile, G.O., Mgbeje, B.I.A., Out, E.A., and Ebong, P.E. (2013). Hepatoprotective and antidiabetic effect of combined extracts of Moringa oleifera and Vernonia amygdalina in streptozotocin induced diabetic albino 
Wistar rats. Journal of Diabetes and Endocrinology, 4(4): 45-50.

El-Hosseiny, L.S., Alqurashy, N.N., and Sheweita, S.A. (2016). Oxidative stress alleviation by sage essential oil in coamoxiclav induced hepatotoxicity in rats. Int. J. Biomed. Sci, 12 (2): 71-78.

Emejulu, A.A., Ujowundu, C.O., and Igwe, C.U. (2010). Hepatotoxicity of antiretroviral drugs in HIV seropositive Nigerian patients. Aust. J. Basic and App Science, 4: 4275-4278.

Friday, E.U., Iniobong, E.O., and Moses, B.E. (2010). Effect of aqueous extract of Psidium guajava leaves on liver enzymes, histological integrity and haematological indices in rats. Gastroenterology Research, 3(1): 32-38.

Hurhmann, D., Weber, R., Enseleit, F., and Luscher, T.F. (2005). HIV infection, antiretroviral therapy and endotherium. Herz, 30 (6): 472-480.

Ibeh, B., Omodamiro, O., Ibeh, U., and Habu, J. (2013). Biochemical and haematological changes in HIV subjects receiving winniecure antiretroviral drug in Nigeria. J. Biomed Sci., 20(1):73

Item, J.A., Patrick, E.E., Godwin, E.E., Mbeh, U.E., and Eyoug, U.E. (2007). Effect of Vernonia amygdalina Del. on liver function in alloxan- induced hyperglycaemic rats. Journal of Pharmacy and Bioresources, 4(1): 1-7.

Jemikalajah, J.D., and Adu, M.E. (2015). Assessment of serum proteins in human immunodeficiency virus patients in Auchi, Nigeria. African Journal of Cellular Pathology, 5: 14-17.

Kapenberg, L.C., Cronje, H.S., and Van Jaarsveld, H. (2004). Serum protein electrophoresis in HIV seropositive and seronegative pregnant women. International Journal of Gynaecology and Obstetrics, 84: 254-258.

Law, W.P., Dore, G.J., and Duncombe, C.J. (2003). Risk of severe hepatotoxicity associated with antiretroviral therapy in the HIV- NAT- cohort, Thailand. AIDS: 2191-2199.

Mankhatithan, W., Lueangniyomkula, A., and Manosuthin, W. (2011). Hepatotoxicity in patients co-infected with tuberculosis and HIV- 1 while receiving nonnucleoside reverse transcriptase inhibitors based antiretroviral therapy and rifampicin containing antituberculosis drugs. Southeast Asian J. Trop. Med. Public Health, 429: 651-658.

Mastroianni, C.M., Lichtner, M., and Mascia, C. (2014). Molecular mechanisms of liver fibrosis in HIV/HCV co-infection. Int. J. Molecular Science, 15: 9184-9204.

Mehta, S.H., Astemborski, J., Sterling, T.R., Thomas, D.L., Vlahov, D. (2006). Serum albumin as a prognostic indicator for HIV disease progression. AIDS Research and Human Retrovirus, 22 (1): 14-21.

Melashu, B.S., Ketema, T.T., Amtatachew, M.Z., and Amarech, A.W. (2016). Liver enzymes abnormalities among highly active antiretroviral therapy experienced and HAART naïve HIV- 1 infected patients at Debre Tabor Hospital, north Western Ethiopia: A comparative cross sectional study. AIDS Research and Treatment, 2016: 1-7. Article ID 1985452.

Okpa, H.O., Oviasu, E., and Ojogwu, L.I. (2015). Microalbuminuria and its relationship with clinical and biochemical parameters in newly diagnosed HIV patients in a tertiary hospital, Southern Nigeria. World Journal of Medical Sciences 12 (2): 8390.

Periklis, P., Efstathios, M., Angelos, H., and Dimitrios, P. (2017). Hyperbilirubinaemia in atazanavir treated HIV-infected patients: The impact of UGT1 A1 28 allele. Pharmagenomics Pers Med., 10: 205-208.

Sarro, Y.S., Tounkara, A., Tangara, E., Guindo, O., White, H. L., Chamot, E., and Kristensen, S. (2010). Serum protein electrophoresis: Any role in monitoring for antiretroviral therapy? African Health Sciences, 10 (2): 138-143.

Subir, K.D., Indranath, G., Debojyoti, B., Praveren, A., Sumanta, J., Anindya, D., Sukanta, K.D. (2013). Liver function profile anomalies in HIV seropositive 
tuberculosis. J Clin Diagn Res., 7(6): 1068-1072.

Sulkowski. M.S. (2004). Drug induced liver injury associated with antiretroviral therapy that includes HIV-1 protease inhibitors. Clin. Infect Dis., 38: 90-97.

Vanwagner, I., and Green, R. (2015). Evaluating elevated bilirubin levels in asymptomatic adults. J. Am. Med. Association, 313 (5):516-517.
Wondemagegn, M., Bokretsion, G., Ambahun, C., Genetu, A., and Bayey, A. (2013) Hepatotoxicity and associated risk factors in HIV-infected patients receiving antiretroviral therapy at Felege Hiwot Referral Hospital, Bahivdar, Ethiopia. Ethiopian Journal of Health Sciences, 23 (3): 217-226. 